\title{
A study on relationship between the return of value/growth portfolio and market return: Evidence from Tehran Stock Exchange
}

\author{
Monireh Mashhadi Ramezanali $^{\mathbf{a}^{*}}$, Mohammadreza Setayesh ${ }^{\mathrm{b}}$ and Mohammad Hassan Janani ${ }^{\mathrm{b}}$
}

${ }^{a}$ M.Sc. Graduate, Department of Financial Management, Science and Research Branch, Islamic Azad University (IAU), Tehran, Iran ${ }^{b}$ Assist. Prof, Science and Research branch, Islamic Azad University (IAU), Brojerd, Iran

\section{H R O N I C L E}

\section{Article history:}

Received January 4, 2014

Accepted 1 June 2014

Available online

June 52014

Keywords:

Market growth and decline

Market return

Value portfolio

\section{A B S T R A C T}

This study examines the relationship between the returns of two value and growth portfolios and the return of market on 15 selected firms on Tehran Stock Exchange over the period 20082011. The study divides the firms into two groups in terms of the ratios of price on earning as well as price on book value into two groups of value and growth portfolios. Using some regression analysis, the study has determined a positive and meaningful relationship between value portfolio and market return when the market is on the upside but this relationship is not meaningful during the bear session. The results indicate that during the bull sessions, value portfolios provide better investment opportunities than growth ones do.

\section{Introduction}

The value effect, in which value stocks substantially outperform growth stocks for investors who can wait to ride out the often-extended time of growth, has been a controversial discussion for years (Sharpe, 1964; Arnott et al. 2009; Fama \& French, 1998, 2002, 2007; Mehra \& Prescott, 1985). Bansal et al. (2005) demonstrated that aggregate consumption risks embodied in cash flows could account for the puzzling differences in risk premia across book-to-market, momentum, and sizesorted portfolios. They discussed that cash flow risk was important for interpreting differences in risk compensation across assets. Blazenko and $\mathrm{Fu}$ (2013) proposed a new explanation for the valuepremium called the limits to growth hypothesis. They found that profitability increases returns to a bigger extent for dividend-paying value companies compared with dividend-paying growth companies, which is consistent with a differential relation between profitability and risk. They also reported that growth firms had lower returns than value firms did. According to Fama and French (1992) used two measured variables of size and book-to-market equity to measure the performance of stock market.

*Corresponding author. Tel: +98-912-5228842

E-mail addresses: mashhadi.m3070@gmail.com (M. M. Ramezanali) 
Lakonisho et al. (1994) provided some evidence that value strategies could result higher returns because these strategies may exploit the suboptimal behavior of the typical investor and not because these strategies would be fundamentally riskier. Petkova and Zhang (2005) studied the relative risk of value and growth stocks and reported that time-varying risk could go in the right direction in explaining the value premium.

\section{The proposed model}

This study examines relationship between the returns of two value and growth portfolios and market return on 15 selected firms on Tehran Stock Exchange over the period 2008-2011. The study divides the data into two groups in terms of market growth and decline and considers the following two hypotheses,

1. During the bear session, the correlation between growth portfolios is bigger than value portfolios.

2. During the bull session, the correlation between value portfolios is bigger than growth portfolios.

The process of selection of firms excludes holding and financial firms and only considers the shares of firms, which were active during the period of investigation. The market return is calculated based on seasonal relative change on market return. Let $r_{1}$ and $r_{2}$ be the returns of the beginning and end of market, respectively. Therefore, market return is calculated as follows,

$r=\frac{r_{2}-r_{1}}{r_{1}}$

The study categorize the firms based on two ratio of price on earning $(\mathrm{P} / \mathrm{E})$ and price on book value (P/BV) into two groups of income and growth. In other words, any firm whose P/E and P/BV values are less than market average is considered income funds and the firms whose $\mathrm{P} / \mathrm{E}$ and $\mathrm{P} / \mathrm{BV}$ are above the average are considered as growth funds. Next, the study determines the relative returns of each fund based on Eq. (1). In our study, variance of return is considered as the risk of each firm as follows,

$$
\sigma^{2}=\frac{\sum_{t=1}^{n}\left(r_{t}-\bar{r}\right)^{2}}{n-1} .
$$

For each portfolio, growth and income, total return is calculated as follows,

$r_{p}=\sum_{i=1}^{k} w_{i} r_{i}$

Next, the risk and return of each fund are calculated based on Eq. (1) and Eq. (2), respectively. Finally, to verify the first and the second hypotheses of the survey, the following two regression models are used, respectively.

$r_{m}=\beta_{0}+\beta_{1}$ Income Fund $+\varepsilon$,

$r_{m}=\beta_{0}+\beta_{1}$ Growth Fund $+\varepsilon$.

\section{The results}

In this section, we present details of our findings on testing two hypotheses of the survey. 


\subsection{The first hypothesis}

The first hypothesis investigates whether the correlation between growth portfolios is bigger than value portfolios or not during the bear session. Eq. (6) shows details of our findings on testing the first hypothesis of this survey.

$$
\begin{array}{rccc}
\multicolumn{4}{c}{r_{m}=27.505+0.197 \text { Income Fund }} \\
\text { t-value } & 2.235 & 0.229 \quad \mathrm{~F}=0.053 \mathrm{R}^{2}=0.017 \\
\text { P-value } & (0.111) & (0.838)
\end{array}
$$

As we can observe from the results of Eq. (6), there is no meaningful between market return and value portfolios. Therefore, we cannot confirm any relationship between the return of value portfolios and market return during the bear session. Eq. (7) demonstrates the results of our survey for bull session.

$$
\begin{array}{rccc}
\multicolumn{4}{c}{r_{m}=16.691+0.472 \text { Growth Fund }} \\
\text { t-value } & 1.461 & 0.591 \quad \mathrm{~F}=0.350 \mathrm{R}^{2}=0.104 \\
\text { P-value } & (0.240) & (0.591)
\end{array}
$$

The results of Eq. (7) are similar to the previous part, which means there is no meaningful relationship between the market return and return of Growth portfolios during the bear session.

\subsection{The second hypothesis}

The second hypothesis investigates whether the correlation between value portfolios is bigger than growth portfolios or not during the bull session. Eq. (8) presents details of our findings on testing the second hypothesis of this survey.

$$
\begin{array}{rccc}
\multicolumn{4}{c}{r_{m}=19.174+1.652 \text { Income Fund }} \\
\text { t-value } & 2.497 & 3.226 \quad \mathrm{~F}=10.407(\text { Sig. }=0.01) \mathrm{R}^{2}=0.536 \\
\text { P-value } & (0.034) & (0.010)
\end{array}
$$

As we can observe from the results of Eq. (8), there is a meaningful between market return and value portfolios. Therefore, we can confirm the relationship between the return of value portfolios and market return during the bull session. Eq. (9) demonstrates the results of our survey for bull session.

$$
\begin{array}{rrrr}
\multicolumn{5}{c}{r_{m}=21.532+0.354 \text { Growth Fund }} \\
\text { t-value } & 3.566 & 0.878 \quad \mathrm{~F}=0.772 \mathrm{R}^{2}=0.079 \\
\text { P-value } & (0.006) & (0.403)
\end{array}
$$

The results of Eq. (9) are similar to the previous part, which means there is no meaningful relationship between the market return and return of growth portfolios during the bull session.

\section{Conclusion}

In this paper, we have presented an empirical investigation to find out about the relationship between market return and growth and value portfolios during the bull and bear sessions. The study has concluded that while there was a strong relationship between market return and value portfolios during the bull session, such relationship did not exist during the bear session. In addition, there was no statistical evidence to believe any relationship between market return and the returns of growth as 
well as value portfolios during the bear sessions. The results of our survey are somewhat consistent with findings of Petkova and Zhang (2005).

\section{Acknowledgement}

The authors would like to thank the anonymous referees for constructive comments on earlier version of this paper.

\section{References}

Arnott, R. D., Li, F., \& Sherrerd, K. (2009). Clairvoyant value II: The growth/value cycle. Journal of Portfolio Management, 35(4), 142-157.

Bansal, R., Dittmar, R. F., \& Lundblad, C. T. (2005). Consumption, dividends, and the cross section of equity returns. The Journal of Finance, 60(4), 1639-1672.

Blazenko, G. W., \& Fu, Y. (2013). Value versus growth in dynamic equity investing. Managerial Finance, 39(3), 4-4.

Fama, E. F., \& French, K. R. (1992). The cross-section of expected stock returns. The Journal of Finance, 47(2), 427-465.

Fama, E. F., \& French, K. R. (1998). Value versus growth: The international evidence. The Journal of Finance, 53(6), 1975-1999.

Fama, E. F., \& French, K. R. (2002). The equity premium. The Journal of Finance, 57(2), 637-659.

Fama, E. F., \& French, K. R. (2007). The anatomy of value and growth stock returns. Financial Analysts Journal, 44-54.

Lakonishok, J., Shleifer, A., \& Vishny, R. W. (1994). Contrarian investment, extrapolation, and risk. The journal of finance, 49(5), 1541-1578.

Mehra, R., \& Prescott, E. C. (1985). The equity premium: A puzzle. Journal of Monetary Economics, 15(2), 145-161.

Petkova, R., \& Zhang, L. (2005). Is value riskier than growth?. Journal of Financial Economics, 78(1), 187-202.

Sharpe, W. F. (1964). Capital asset prices: A theory of market equilibrium under conditions of risk. The journal of finance, 19(3), 425-442. 